\title{
Benzimidazole Resistance: An Overview
}

\author{
D.B. Bhinsara ${ }^{1 *}$, M. Sankar ${ }^{2}$, D.N. Desai ${ }^{3}$, J.J. Hasnani ${ }^{1}$, P.V. Patel ${ }^{1}$, \\ N.D. Hirani ${ }^{1}$ and V.D. Chauhan ${ }^{1}$ \\ ${ }^{1}$ Department of Veterinary Parasitology, Anand Agricultural University, \\ Anand-388 001, Gujarat, India \\ ${ }^{2}$ Division of Temperate Animal Husbandry, Indian Veterinary Research Institute, \\ Mukteswar campus, Nainital -243186, India \\ ${ }^{3}$ Department of Veterinary Microbiology, Navsari Agricultural University, \\ Navsari -396 450, Gujarat, India \\ *Corresponding author
}

\section{A B S T R A C T}

\begin{tabular}{|c|}
\hline Keywords \\
\hline $\begin{array}{l}\text { Benzimidazole } \\
\text { resistance, } \\
\text { Anthelmintic, } \\
\text { Nematode and } \\
\text { epidemiology }\end{array}$ \\
\hline Article Info \\
\hline $\begin{array}{l}\text { Accepted: } \\
26 \text { January } 2018 \\
\text { Available Online: } \\
\text { 10 February } 2018\end{array}$ \\
\hline
\end{tabular}

\begin{abstract}
Anthelmintic drug resistant rising the major threat for the animal population. Benzimidazole group of anthelmintic drug are most popular and used drug in nematodal control strategy. High treatment frequency, single-drug regimens, targeting the mass treatments, under-dosing, improper use of anthelmintic, improper management, unguided and unaddressed policy of nematodal control leads to the resistant among the animal population which become main source of transferring and migrating the resistant to another. Selection pressure act majorly in escaping the treatment. Genetic as well as acquired factors are also play a role diversely in the resistance. Based on the current available knowledge and parameters, we have reviewed the epidemiological consideration of persistent prevalence, factors, and mechanism of benzimidazole (BZ) resistance which may further open the door for the researcher, investigator and policy maker for its control and standardizing the guideline.
\end{abstract}

\section{Introduction}

BZ resistance in gastrointestinal parasitism has been reviewed by many authors and particularly anthelmintic resistance in trichostrongylid nematodes have been thoroughly reviewed by Le Jampre (1978) and Prichard et al., 1980. BZ resistance in GI parasitism has great epidemiological significance and there is also evidence that resistant parasites are more fecund, more pathogenic, increased establishment rates in the host as well as survival in free living stages (Kelly et al., 1977). BZ has been the mainstay drugs for the last five decades to control the Gastro-Intestinal (GI) nematodes, have resulted in the co-evolution of resistant parasites across the globe including India (Gill, 1996; Silvestre and Humbert, 2000; Garg and Yadav, 2009). Among different classes of anthelmintics, BZs are most widely used to control gastrointestinal nematode infections in small domestic ruminants due its high therapeutic index and ratio, absence of 
drug residue in milk and meat and also economically viable (Humbert et al., 2001). As a result of their continued use, resistance to BZ drugs has emerged world-wide within trichostrongylid parasitic nematodes including India (Gill, 1993; Waller, 1997; Jackson and Coop, 2000; Swarnkar et al., 1999a, 1999b, 2001).

BZ resistance in strongyle nematodes are principally linked to alteration in the gene that encodes for $\beta$ - tubulin isotype 1. This knowledge of the molecular basis of the resistance to xenobiotic has allowed the development of PCR based methods for their detection. Although numerous mutations of $\beta$ tubulin gene are candidates under experimental conditions, BZ-resistance in the three main gastrointestinal nematodes of sheep (Teladorsagia circumcincta, Trichostrongylus vitrinus and Haemonchus contortus) seems to be primarily linked to a point mutation in position 200 of isotope $1 \beta$-tubulin gene, which replaces a phenylalanine (Phe) with a tyrosine (Tyr) (Kwa et al., 1993a, 1993b, 1994, 1995; Elard et al., 1996; Elard et al., 1999). However, mutations at 167 (Phe to Tyr) and 198 (Glu to Ala) are also reported to be associated with resistance in some isolates (Prichard, 2001; Ghisi et al., 2007; Rufener et al., 2009). The codon 200 polymorphism has also been found in small strongyles (Cyathostominae) of the horse (Pape et al., 1999; Von Samson-Himmelstjerna et al., 2001). Based on polymorphism between resistance and susceptible population, several papers have described methods for genotyping different stages of the three trichostrongyloid species of sheep (Kwa et al., 1994; Elard et al., 1999; Silvestre and Humbert, 2000; Garg and Yadav, 2009; Chandra et al., 2014, 2015) and in small strongyles (Von SamsonHimmelstjerna et al., 2002a, 2002b). Allele specific PCR (AS-PCR) is effective method to identify point mutation (Silvestre and Humbert, 2000). Alvarez-Sánchez et al.,
(2005) performed real time PCR on isotype 1 of $\beta$-tubulin, strains of the main species of trichostrongylids (T. circumcincta, $H$. contortus and $T$. vitrinus) that are susceptible and resistant to $\mathrm{BZ}$ were differentiated.

\section{Anthelmintic drug resistance}

Gastrointestinal nematodes infections of livestock cause serious economic losses, in particular areas where extensive grazing is practiced. Fortunately, the availability of safe, broad spectrum anthelmintics have helped to reduce the incidence of great number of the worm diseases (Prichard, 1990). Modern anthelmintics are highly effective against the mature and immature stages of virtually all of the important gastrointestinal nematodes as well as many extra-intestinal nematodes. However, over rely on anthelmintics, extensive use and improper dosage of anthelmintics in conjunction with other factors has resulted in drug resistance, causing serious threat to effective control of helminth infections (Sangster, 1996).

Prichard (1980) defined resistance is present when there is a greater frequency of individuals within a population able to tolerate doses of a compound than in a normal population of the same species and is heritable. Side resistance exists, where the resistance to a compound is the result by selection by another compound with a similar mode of action. Cross-resistance resembles side resistance but involves compounds with different modes of action. Multiple resistance induced by multiple selection with anthelmintics same or different group has been demonstrated (Soulsby 1982). For instance, thiabendazole and parbendazole resistance parasites have been found to be cross resistance to other benzimidazole anthelmintics (Berger, 1975; Hall et al., 1978). Multiple resistances occur when individuals are resistant to two or more different 
anthelmintic groups either as a result of selection by each group independently or as a result of cross-resistance. Reversion is a decrease in the frequency if resistant individuals in a population following removal of the selecting agent.

Animals raised under grazing conditions are highly susceptible to various parasites and the primary control method is through the use of broad-spectrum anthelmintics (Waller, 1997). However, the indiscriminate use of these drugs without appropriate association with other methods to fight parasite infection has favored the development of helminth resistance to various drugs in the gastrointestinal strongyles of the small ruminants (Morales and Pino, 2001).

\section{Development of anthelmintic resistance and its persistence}

BZ's are believed to exert their effect on the parasites by binding to the tubulin protein and preventing it polymerizing into microtubules (Lacey, 1988). One critical question about BZ resistance concerns the origin of the $\mathrm{BZ}$ resistance alleles in worm population. These alleles may arise by spontaneous mutation or by migration. But anthelmintic resistance in nematodes is thought to be pre-adaptive phenomenon.

This implies that resistant populations are often considered to be present in the normal population as a rare allele prior to use of any drug. Studies with other models of resistance to xenobiotic demonstrated that migration plays a fundamental role in dispersion of insecticide resistance genes in mosquitoes (Raymond et al., 1991), and of antibiotic resistance among some species of bacteria (O'Brien, 1997). In such cases, measures can be adopted to limit the spread of the resistance alleles. But, when the resistant alleles are present as a rare allele in a population, the spread of resistance is more difficult to prevent since the anthelmintic treatments will inevitably constitute a selection pressure in favour of this rare alleles (Humbert, et al., 2001). According to Wood and Mani (1981) the problem of resistance is multidimensional. It is a physiological or a biochemical property, its inheritance is genetical, the development of genetic strains is evolutionary and finally the evolution of resistance depends on ecological factors, which varies with species, population and location. Prichard (1990) summarized the intricate phases of the selected process such as susceptibility phase, intermediate phase and resistant phase. In susceptibility phase, the frequency of resistant individuals within the population is low. The intermediate phase develops when continued exposure to a drug, in which the frequency of heterozygous resistant individuals within the population increases. Finally, sustained selection pressure results in resistant phase, where the homozygous resistant individuals predominate within the population. The selection of resistant is most rapid when both heterozygous and homozygous resistant individual survive treatments.

\section{Factors accelerating the resistance}

Many factors are contributing the development of resistance, however frequent dosing of anthelmintics heads the list. Studies on nematodes (Round et al., 1974; Barton, 1980, 1983; Martin et al., 1982, 1984) clearly demonstrated that frequent dosing favours the resistance more strongly than less frequent dosing regimens. The reason is that the resistant genotypes are not affected by the treatment and continue to reproduce. While, the susceptible populations acquired from pasture are eliminated without reproducing offspring. Frequent dosing practice in goats has resulted in a high incidence of BZ resistance (Jackson, 1993). 
BZ resistance has evolved in a variety of organisms and typically results from mutations in the $\beta$-tubulin locus at specific amino acid sites. $\beta$-tubulin mutations conferring resistance are generally recessive, frequencies of resistance alleles less than $30 \%$ would be difficult to detect on the basis of drug treatment failure (Bennett, 2002). When resistant is present at detectable levels in the field, the responsible alleles will be abundant in the gene pool due to the recessive nature of $\mathrm{BZ}$ resistance alleles in nematodes (Anderson et al., 1998; Elard et al., 1999).

Next to frequent dosing is under dosing. Under dosing favours the selection of resistant genes in a population of susceptible individuals (Coles et al., 1992). Doses high enough to eliminate heterozygous genes for resistance render this trait become recessive, whereas under doses make effectively dominant (Roush and Mckenzie, 1987).

By using under doses, heterozygous individuals are allowed to survive and contribute resistant genes to subsequent generations. Another potential contributor to under dosing is where a single host harbour different type of parasites with different susceptibilities to a drug and the drug is used at the dose sufficient for more sensitive organisms on a spot basis. Inadequate attention to calibrate or condition of dosing equipment might be lead to delivery of under dose.

Management of parasites can contribute in a variety of ways to the generation of resistance. Cawthorne and Cheong (1984) reported that the movement of stock rather than use of anthelmintics as the main source of resistance. When introducing new animals from anthelmintic resistance prone areas to another farm without appropriate quarantine, disease monitoring, and treatment can rapidly sets in resistance problems.
Next, free living stages in the environment play a major role in enhancing the rate of development of resistance. Treatment was given, when the free living stages of parasite are susceptible to cold, reduction in the number of parasites in pasture, leaving the major source of subsequent infection to be the progeny of those worms which are resistant and survive treatment (Taylor, 1990; Sykes et al., 1992).

But when the proportions of free-living worms are more, the offspring of the resistant worms will be diluted and resistance will be slow to develop.

The resistant worms have higher fecundity and increased establishment rates in the host than susceptible worms (Kelly et al., 1978; Kelly and Hall, 1979). Dosing animals and moving them to clean pasture is essential for resistant control.

But, some researchers (Le Jambre, 1978; Taylor and Hunt, 1989; Smith, 1990) demonstrated that moving the animals to clean pasture after treatment favour the resistant gene selection. In this case, those worms that are resistant and survive treatment would be the major contributors to subsequent infection.

Physiological phenomena can also contribute to development of resistant population. In ruminant animals, the esophageal groove reflex can result in drug getting into an inappropriate compartment, where it is rendered ineffective or less effective resulting in enhanced rate of development (or) selection of resistant worms (Hennessy, 1994; Sanyal, 1994; Sanyal and Godke, 1996; Swarnkar et al., 1999a; Singh et al., 2002). Pharmacokinetics differences between individual animals and breeds of the same species can effect dose requirements and contribute to resistant population (Coles et al., 1989; Sangster et al., 1991). 
Table.1 Reports of anthelmintic resistance from India

\begin{tabular}{|c|c|c|c|c|}
\hline Region/Place & Host & Drug & Method & References \\
\hline \multicolumn{5}{|l|}{ Northern India } \\
\hline Uttar Pradesh & Sheep & Phenothiazine \& thiabendazole & FECRT & Varshney and Singh, 1976 \\
\hline Haryana & Sheep & Benzimidazole & FECRT & Yadav, 1990 \\
\hline Haryana & Goat & Levamisole & FECRT & Yadav et al., 1992 \\
\hline Haryana & Goat & Multiple except IVM & FECRT & Uppal et al., 1992 \\
\hline Himachal Pradesh & Sheep & Benzimidazole & FECRT & Singh et al., 1992 \\
\hline Haryana & Sheep & Multiple except IVM & FECRT & Yadav et al., 1993 \\
\hline Haryana & Sheep & Benzimidazole & FECRT & Kumar and Yadav, 1994 \\
\hline Haryana & Sheep & Multiple except IVM & FECRT & Yadav et al., 1995 \\
\hline Uttar Pradesh & Sheep & Benzimidazole \& Levamisole & FECRT & Srivastava et al., 1995 \\
\hline Uttar Pradesh & Goat & Benzimidazole & FECRT & Yadav et al., 1996 \\
\hline Haryana & Cattle & Morantel & FECRT & Yadav and Verma, 1997 \\
\hline Haryana & Sheep \& Goat & Benzimidazole & FECRT & Singh et al., 1997 \\
\hline Uttar Pradesh & Goat & Bnzimidazole & FECRT & Garg et al., 2004 \\
\hline $\begin{array}{l}\text { Uttar Pradesh and } \\
\text { Uttarkhand }\end{array}$ & Sheep \& goat & Benzimidazole & EHT, ASPCR & Sankar, 2003, 2007 \\
\hline Haryana & Sheep & Multiple & FECRT & Chaudhri et al., 2007 \\
\hline Uttarkhand & Goats & Benzimidazole & FECRT & Ram et al., 2007 \\
\hline $\begin{array}{l}\text { Uttar Pradesh and } \\
\text { Uttarkhand }\end{array}$ & Sheep & Benzimidazole & ASPCR & Garg and Yadav, 2009 \\
\hline Punjab & Sheep & Multiple & FECRT & Buttar et al., 2011, 2012 \\
\hline Uttarkhand & Sheep and goat & Benzimidazole & $\begin{array}{l}\text { FECRT EHA } \\
\text { LDA }\end{array}$ & Rialch et al., 2013 \\
\hline Uttar Pradesh & $\begin{array}{l}\text { Sheep } \\
\text { Goats }\end{array}$ & Benzimidazole & FECRT ASPCR & Chandra et al., 2014, 2015 \\
\hline \multicolumn{5}{|l|}{ Central India } \\
\hline Maharastra & Sheep and Goat & Multiple & FECRT PCR-RFLP & Ghalsasi et al., 2012 \\
\hline Chattisgarh & Goat and cattle & Multiple & FECRT EHT & Kumar et al., 2014 \\
\hline \multicolumn{5}{|l|}{ Southern India } \\
\hline Tamilnadu/Andhra & Sheep & Benzimidazole \& Levamisole & FECRT & Gill, 1996 \\
\hline Tamilnadu & Sheep & Benzimidazole & FECRT & Jeyathilakan et al., 2003 \\
\hline Tamilnadu & Sheep & Benzimidazole & $\begin{array}{l}\text { FECRT } \\
\text { EHT }\end{array}$ & Sundaram et $a l ., 2005$ \\
\hline Tamilnadu & Sheep \& goat & Benzimidazole & EHA, ASPCR & Sankar, 2003, 2007 \\
\hline Tamilnadu & Sheep & Benzimidazole \& Levamisole & FECRT, EHA & Easwaran et al., 2009 \\
\hline Kerala & Goat & Benzimidazole \& Ivermectin & FECRT & Rajagopal et al., 2013 \\
\hline \multicolumn{5}{|l|}{ Western India } \\
\hline Rajasthan & Sheep & Benzimidazole & FECRT, EHA & Singh et al., 1995 \\
\hline Rajasthan & Sheep & Refoxanide & FECRT & Singh et al., 1996 \\
\hline $\begin{array}{l}\text { Rajasthan } \\
\text { Gujarat } \\
\end{array}$ & Sheep & Benzimidazole \& Levamisole & FECRT & Gill, 1996 \\
\hline Rajasthan & Sheep & $\begin{array}{l}\text { Benzimidazole, Levamisole \& } \\
\text { Refoxanide }\end{array}$ & FECRT, EHA & $\begin{array}{l}\text { Swarnkar et al., 1999a, } \\
\text { 1999b }\end{array}$ \\
\hline Rajasthan & Sheep & Benzimidazole \& Refoxanide & FECRT, LDA & Swarnkar et al., 2001 \\
\hline Rajasthan & Sheep & Benzimidazole & $\begin{array}{l}\text { PCR-RFLP } \\
\text { ASPCR }\end{array}$ & Tiwari et al., 2006, 2007 \\
\hline Gujarat & Sheep & $\begin{array}{l}\text { Multiple resistance including } \\
\text { IVM }\end{array}$ & FECRT & $\begin{array}{l}\text { Makvana and Veer Singh, } \\
2009\end{array}$ \\
\hline Rajasthan & Goats & $\begin{array}{l}\text { Multiple resistance including } \\
\text { IVM }\end{array}$ & FECRT & Godara et al., 2011 \\
\hline Rajasthan & Sheep & Benzimidazole and Levamisol & FECRT and EHT & Maharshi et al., 2011 \\
\hline \multicolumn{5}{|l|}{ Eastern India } \\
\hline West Bengal & Sheep \& Goat & Benzimidazole & EHA, ASPCR & Sankar, 2003, 2007 \\
\hline Orissa & Goat & Multiple & FECRT & Sarangi et al., 2014 \\
\hline
\end{tabular}


Sheep and goats should not be kept on the same farm. The first reports of Ivermectin resistance in USA (Craig and Miller, 1990) and in New Zealand (Watson and Hosking, 1990) were derived from goats. Anthelmintic resistance was more common in goat farms (Kettle et al., 1983) than sheep farms (Mckenna, 1989). The rearing of goats with cattle reduce worm burdens (Bisset et al., 1988), but resistant nematodes may be transmitted from goats to sheep if they are grazed together on the same pasture during the same year or in the spring and early summer of the following year. In these situations, goats are treated with higher doses than sheep (Coles et al., 1989).

In India, anthelmintic treatment for sheep and goats, cattle and buffalo are grouped together and recommended similar dose rate. Sanyal and Godke (1996) reported that pharmacokinetics of BZ differs in sheep \& goat and cattle and buffalo. Sanyal (1993, 1994) and Singh et al., (2002) reported metabolism of BZ is faster in goats than sheep and buffalo than cattle. Thus, use of sheep dose in goats and cattle dose in buffaloes may enhance the selection pressure and favour to the resistant alleles. In India, farmers are not consulting their veterinary surgeons for managemental practices and they are treating their animals without correct information about anthelmintic dose. And also lack of knowledge of epidemiology of parasitic infection increases the spread of anthelmintic resistance to all over the country.

\section{Extent of resistance to worldwide}

Anthelmintic resistance has been developed against all classes of broad-spectrum anthelmintics and has been recorded from many countries throughout the world (Prichard, 1990; Jackson, 1993). Resistance against BZ is extensively reported in sheep and goats, and in some parts of the world it is a serious problem. Van Wyk et al., (1989) reported that the farmers in South Africa are getting out of business because there are no drugs are effective in controlling the multiresistant nematode populations. Rolfe et al., (1990) reports, "Resistance to anti-parasitic agents in sheep has emerged as the most important limitation for successful production of wool and meat in Australia". Waller et al., (1996) suggested that anthelmintic resistance is wide spread in the high rainfall areas of East African countries such as Kenya, Tanzania, Zimbabwe and South American countries such as Argentina, Brazil and Uruguay. Resistance to anthelmintics could also become a problem for wildlife. The role of wild ruminants in spreading AR helminths has already been confirmed by Praslicka et al., (1995). Among all anthelmintics, BZ resistance is the major problem and extensively reported from different countries (Van Wyk, et al., 1989; Prichard, 1990; Taylor, 1990; Borgsteede, 1993). Since BZ resistance recorded in 1964, three years after thiabendazole (TBZ) was introduced biochemically (Drudge et al., 1964). Many authors reported that the anthelmintic resistance in sheep nematodes from different countries. In New Zealand (Mckenna et al., 1990), South Africa (Van Wyk et al., 1987; Van Wyk and VanSchalkwyk, 1990), England (Taylor, 1990; Coles et al., 1988, 1992) Australia (Edward et al., 1986; Waller et al., 1996; Love et al., 1992), Netherlands (Borgsteede, 1986, 1990) and France (Silvestre and Humbert 2000; Silvestre et al., 2000, 2001; Humbert et al., 2001), Canada (Barrere et al., 2013), Brazil (Dos Santos et al., 2014) and USA (Chaudhary et al., 2014).

Earlier surveys and reports were restricted to single drug (or) single species of nematodes. Thereafter, the reports were extended to multi-generic resistance (Hall et al., 1981; Barton et al., 1985; Martin et al., 1985; Bauer et al., 1987; McKenna, 1989; Watson and 
Hosking, 1990; Hong et al., 1992) and multi drug resistance (Sangster et al., 1979, 1985; Sangster, 1990, 1996; Van Wyk et al., 1987, 1989; Jackson et al., 1992; Love et al., 1992; Uppal et al., 1992).

\section{Prevalence of anthelmintic resistance in India}

Reports of anthelmintic resistance from India are scanty and scattered and also maximum reports are from farms based on conventional diagnostic methods (Table 1) also the maximum reports pertaining BZs, Levamisole and Rafoxanide, however, few reports of Ivermectin resistance are also available recent years.

Many of the earliest reports emanated from the northern India; however, later reports are also from other parts of the country and usually involved species with a high biotic potential such as $H$. contortus. Although the rate of emergence of resistant strains has generally been slower due to recessive in nature, the prevalence of resistance is also increasing throughout country particularly organised farm of small ruminants and horses.

The first report of AR in India by Varshney and Singh on 1976 at Sheep breeding farm, Pashulok, Rishikash, subsequent report of fenbendazole resistance was from sheep farm in Hissar, Haryana by Yadav (1990) followed by levamisole resistance (Yadav et al., 1992). Hereafter, many reports were poured from many parts of the country particularly from Haryana, Rajasthan and Uttar Pradesh against all groups of anthelmintics except Ivermectin.

Since 2002, the prevalence of AR has been reported from all part of the country and few reports were based on advanced molecular techniques PCR-RFLP and AS-PCR (Tiwari et al., 2006; Sankar, 2007; Tiwari et al., 2007; Garg and Yadav, 2009; Rialch et al., 2014;
Chandra et al., 2014, 2015; Chaudhry et al., 2015). However, our understanding of the genesis of anthelmintic resistance is meagre. Lack of concrete knowledge about epidemiology of parasites, unaware of $\mathrm{AR}$ particularly among farmers, inadequate facility to diagnosis and monitoring are the major issues in the area of anthelmintic resistance in India. Further, indiscriminate grazing system, diversity in climatic pattern, various agro-climatic zones with geographical variations and nomadic nature of sheep rearing are complicating the research on anthelmintic resistance.

Resistance to anthelmintic drugs in large and small ruminants has emerged as the most important limitation for successful production of milk, meat and other product. Basically the resistance has emerged very fast, even evolving its way to counter the drugs day by day. The field isolates are known to show resistance to all the available classes of anthelmintic. Historically, resistance has emerged rapidly in sheep and goat against each new class of anti-nematodal drugs. In some countries, situation is serious, that it has resulted in abandoning of livestock population.

Anthelmintic resistance coming up with alarming for the next generation for their survival, sustain and productivity. To counter the resistance, it required more basic research in the direction to find out the actual mechanism as well as their adaptive index which make them resistant in natural as well as in adverse conditions. Based on experience, some recommendations should be made by government to reduce the risk of development of drug resistance. The dramatic and rapid spread of resistance to all major classes of anthelmintics should be a warning against too strong a reliance on drugs in helminth control programmes in veterinary practice. 


\section{References}

Alvarez-Sanchez., M.A., Perez-Garcia, J., CruzRojo, M.A. and Rojo-Vazquez, F.A. 2005. Real time PCR for the diagnosis of benzimidazole resistance in trichostrongylids of sheep. Vet. Parasitol. 129(3): 291-298.

Anderson, T.J., Blouin, M.S. and Beech, R.N. 1998. Population biology of parasitic nematodes: applications of genetic markers. Adv. Parasitol. 41: 219-283.

Barrere, V., Falzon, L.C., Shakya, K.P., Menzies, P.I., Peregrine, A.S. and Prichard, R.K. 2013. Assessment of benzimidazole resistance in Haemonchus contortus in sheep flocks in Ontario, Canada: comparison of detection methods for drug resistance. Vet. Parasitol. 198(1): 159-165.

Barton, N. J. 1980. A review of the pharmacology and clinical use of ivermectin. Can. Vet. J. 28: 512-517.

Barton, N. J. 1983. Emergence of Haemonchus contortus resistant to thiabendazole. Aus. Vet. J. 56: 46-47.

Barton, N.J., Trainor, B.L., Urie, J.S., Atkins, J.W., Pyman, M.F.S. and Wolstencroft, I.R. 1985. Anthelmintic resistance in nematode parasites of goats. Aus. Vet. J. 62: 224-227.

Bauer, C., Ullirich, D., Fiege, N., Koing, D., Luft, W. and Burger, H.J. 1987. Benzimidazole resistance in Haemonchus contortus on a sheep farm in southern Germany. Dtsch. Tierarztl. Wochenschr. 94: 205-206.

Bennett, A.B., Anderson, T.J.C., Barker, G.C., Michael, E. and Bundy, D.A.P. 2002. Sequence variation in the Trichuris trichiura $\beta$-tubulin locus: implications for the development of benzimidazole resistance. Int. J. Parasitol. 32(12): 1519-1528.

Berger, J. (1975). The resistance of a field strain of Haemonchus contortus to five benzimidazole anthelmintics in current use. Journal of the South African Veterinary Association, 46(4), 369-372.

Bisset, S. A., McMurtry, L. M., Vlassoff, A. and West, C. J. 1988. Anthelmintic resistance to two drench families in a dairy goat herd: suggestion for future control options. New Zealand Vet. J. 36: 201-203.

Borgsteede, F. H. M. 1993. Anthelmintic resistance in nematodes of sheep and goats.
Anthelmintic resistance in nematodes of Farm Animals. A seminar organized for the European Commission, Brussels, Belgium. 8: 1-16.

Borgsteede, F.H.M. 1986. Resistance of Cooperia curticei against fenbendazole. Res. Vet. Sci. 41: 423-424.

Borgsteede, F.H.M. 1990. Anthelmintic resistance in gastrointestinal nematodes of herbivorous animals in Europe. In Resistance of parasites to antiparasitic drugs: Round Table Conference, ICOPA VII Paris 1990. (pp. 8187). Merck \& Co. Inc.

Buttar, B.S., Rai, H.S., Singh, N.K., Haque, M. and Rath, S.S. 2012. Emergence of Anthelmintic resistance in an organized sheep farm in Punjab. J. Vet. Parasitol. 26(1): 6971.

Buttar, B.S., Rai, H.S., Singh, N.K., Kaur, A. and Rath, S.S. 2011. Detection of anthelmintic resistance in naturally occurring gastrointestinal nematodes in unorganized sheep farms. Indian J. Vet. Res. 20(1): 22-25.

Cawthrone, R.J.G and Cheong, F.H. 1984. Prevalence of anthelmintic resistant nematodes in sheep in south- east England. Vet. Rec. 114: 562-564.

Chandra, S., Prasad, A., Sankar, M., Yadav, N. and Dalal, S. 2014. Molecular diagnosis of benzimidazole resistance in in Haemonchus contortus in sheep from different geographic regions of North India. Vet. World, 7(5): 337341.

Chandra, S., Prasad, A., Yadav, N., Latchumikanthan, A., Rakesh, R.L., Praveen, K., Khobra, V., Subramani, K.V., Misri, J. and Sankar, M. 2015. Status of benzimidazole resistance in Haemonchus contortus of goats from different geographic regions of Uttar Pradesh, India. Vet. Parasitol. 208(3): 263267.

Chaudhri, S.S., Gupta, S.K. and Bisla, R.S. 2007. Resistance of gastrointestinal nematodes to tetramisole hydrochloride, morantel tartrate and fenbendazole in sheep of Haryana. J. of Vet. Parasitol. 21(2): 113-115.

Chaudhry, U., Miller, M., Yazwinski, T., Kaplan, R. and Gilleard, J. 2014. The presence of benzimidazole resistance mutations in Haemonchus placei from US cattle. Vet. Parasitol. 204(3): 411-415. 
Chaudhry, U., Redman, E.M., Abbas, M., Muthusamy, R., Ashraf, K. and Gilleard, J.S. 2015. Genetic evidence for hybridisation between Haemonchus contortus and Haemonchus placei in natural field populations and its implications for interspecies transmission of anthelmintic resistance. Int. J. Parasitol. 45: 149-159.

Coles, G. C., Bauer, C., Borgsteede, F. H. M. and Geerts, S. 1992. World association for the advancement of Veterinary Parasitology (WAAVP) methods for the detection of anthelmintic resistance in nematode of veterinary importance. Vet. Parasitol. 44: 3544.

Coles, G. C., Tritschler, J. P. and Giordano, D. L. 1989. Efficacy of levamisole against immature and mature nematodes in goats with induced infections. Am. J. Vet. Res. 50: 1074-1075.

Coles, G. C., Tritschler., J. P., Giordano, D. J., Laste, N. J. and Schmidt, A. L. 1988. Larval development test for detection of anthelmintic resistant nematodes. Res. Vet. Sci. 45: 50-53.

Craven, J., Bjorn, H., Barnes, E.H., Henriksen, S.A. and Nansen, P. 1999. A comparison of in vitro tests and a faecal egg count reduction test in detection of anthelmintic resistance in horse strongyles. Vet. Parasitol. 85(1): 49-59.

Criag, T. M and Miller, D. K. 1990. Resistance by Haemonchus contortus to ivermectin in Angora goats. Vet. Re. 126: 580.

Dos Santos, J.M.L., Monteiro, J.P., Ribeiro, W.L.C., Macedo, I.T.F., CamurçaVasconcelos, A.L.F., da Silva Vieira, L. and V Bevilaqua, C.M.L. 2014. Identification and quantification of benzimidazole resistance polymorphisms in Haemonchus contortus isolated in Northeastern Brazil. Vet. Parasitol. 199(3): 160-164.

Drudge, J. H., Szanto., Wyant, Z. W. and Elam, G. W. 1964. Field studies on parasite control in sheep: Comparison of thiabendazole, ruelene and phenothiazine. Am. J. Vet. Res. 25: 1512-1518.

Easwaran, C., Harikrishnan, T.J. and Raman, M. 2009. Multiple anthelmintic resistance in gastrointestinal nematodes of sheep in Southern India. Veterinarski Arhiv. 79(6): 611-620.

Edward, J.R., Wroth, R., deChaneet, G.C., Besier,
R.B., Karlsson,J., Morcombe P.W., DaltonMorgan, G. and Robert, D. 1986. Survey of anthelmintic resistance in Western Australian sheep flocks. I. Prevalence. Aus. Vet. J. 63: 135-138.

Elard, L., Cabaret, J. and Humbert, J. F. 1999. PCR diagnosis of benzimidazole susceptibility or resistance in natural populations of the small ruminant parasite. Teladorsagia circumcincta. Vet. Parasitol. 80: 231-237.

Elard, L., Comes, A. M. and Humbert, J. F. 1996. Sequences of $\beta$-tubulin cDNA from benzimidazole-susceptible and resistant strains of Teladorsagia circumcincta a nematode parasite of small ruminants. Mol. Biochem. Parasitol. 79: 249-253.

Fleming, S.A., Craig, T., Kaplan, R.M., Miller, J.E., Navarre, C. and Rings, M. 2006. Anthelmintic resistance of gastrointestinal parasites in small ruminants. J. Vet. Internal Med. 20(2): 435-444.

Garg, and Yadav. 2009. Genotyping of benzimidazole susceptible and resistant alleles in different populations of Haemonchus contortus from Himalayan and sub-Himalayan regions of North West India Trop. Anim. Health Prod. 41 (7): 11271131.

Garg, R., Yadav, C.L., Kumar, R.R., Banerjee, P.S., Vatsya, S. and Godara, R. 2009. The epidemiology of fasciolosis in ruminants in different geo-climatic regions of north India. Trop. Anim. Health Prod. 41(8): 169517.

Garg, S.K., Katoch, R. and Chauhan, P.P.S. 2004. Evaluation of the efficacy of fenbendazole against natural gastrointestinal nematodiasis in goats (Capra hircus). Small Rum. Res. 51(1): 97-100.

Ghalsasi, P.P., Saste, S.R., Ghalsasi, P.M. and Nimbkar, C. 2012. Emergence of benzimidazole resistance in nematodes of small ruminants in an organized farm and some small holder flocks in Phaltan Taluka, Maharashtra. J. Vet. Parasitol. 26(2):95-98.

Ghisi M., Kaminsky R. and Mäser P. 2007. Phenotyping and genotyping of Haemonchus contortus isolates reveals a new putative candidate mutation for benzimidazole resistance in nematodes. Vet. Parasitol. 
144(3): 313-320.

Gill, B. S. 1993. Anthelmintic resistance in India. Vet. Rec. 133: 603-604.

Gill, B. S. 1996. Anthelmintic resistance in India. Vet. Parasitol. 63: 173-176.

Godara, R., Sharma, R.L. and Sodhi, S.S. 2011. Efficacy of fenbendazole, levamisole and ivermectin against gastrointestinal nematodes in Jamunapari goats. J. Parasit. Dis. 35(2): 219- 221.

Hall, C. A., Kelly, J. D., Campbell, N. J., Whitlock, H. V., \& Martin, I. C. (1978). The dose response of several benzimidazole anthelmintics against resistant strains of Haemonchus contortus and Trichostrongylus colubriformis selected with thiabendazole. Research in veterinary science, 25(3), 364-367.

Hall, C. A., Ritchie, L. and McDonell, P. A. 1981. Investigation for anthelmintic resistance in gastrointestinal nematodes from goats. Res. Vet. Sci. 31: 116-119.

Hennessy, D. R. 1994. The disposition of anitparasitic drugs in relation to the development of resistance by parasites livestock. Acta Tropica, 56: 125-141.

Hong, C., Hunt, K. R., Haris, T. J., Coles, G. C., Grimshaw, W. T. R. and McMullin, P. F. 1992. A survey of benzimidazole resistant nematodes in sheep in three counties of Southern England. Vet. Rec. 131: 5-7.

Humbert, J. F., Cabaret, J., Elard, L., Leignel, V. and Silvestre, A. 2001. Molecular approaches to studying benzimidazole resistance in trichostrongylid nematode parasites of small ruminants. Vet. Parasitol. 101: 405-414.

Jackson, F. 1993. Anthelmintic resistance. The state of play. Brit. Vet. J. 149: 123-138.

Jackson, F. and Coop, R.L. 2000. The development of anthelmintic resistance in sheep nematodes. Parasitol. 120(7): S95S107.

Jackson, F., Coop, R. L., Jackson, E., Scott, E.W, and Russel, A. J. F. 1992. Multiple anthelmintic resistant nematodes in goats. Vet. Rec. 130: 210-211.

Jeyathilakan, N., Radha, G., Gomathinayagam, S. and John, L. 2003. Emergence of anthelmintic resistance in nematodes of sheep in Tamil Nadu. J. Vet. Parasitol. 17: 159-160.

Kelly, J. D and Hall, C. A. 1979. Resistance of animal helminths to anthelmintics. Adv. Pharm. Chemo. 16: 89-128.

Kelly, J. D., Hall, C. A., Whitlock, H. V., Thompson, H. G., Campbell, N. J., \& Martin, I. C. (1977). The effect of route of administration on the anthelmintic efficacy of benzimidazole anthelmintics in sheep infected with strains of Haemonchus contortus and Trichostrongylus colubriformis resistant or susceptible to thiabendazole. Research in veterinary science, 22(2), 161-168.

Kelly, J. D., Whitlock, H. V., Thompson, H. G., Hall, C. A., Martin, I. C. A. and Le Jambre, L. F. 1978. Physiological characteristics of free- living and parasitic stages of strains of Haemonchus contortus susceptible or resistant to benzimidazole anthelmintics. Res. Vet. Sci. 25: 376-385.

Kettle, P. R., Vlassoff, A., Reid, T. C. and Horton, C. T. 1983. A survey of nematode control measures used by milking goat farmers and of anthelmintic resistance on their farms. New Zealand Vet. J. 31: 139-143.

Kumar, D., Sanyal, P.K., Wahane, N., Pal, S., Bisen, S. and Baghel, K.R. 2014. Evidence of anthelmintic resistance in ruminants of Jashpur district of Chhattisgarh. Indian J. Small Rum. 20(2):62-65.

Kumar, R and Yadav, C. L. 1994. Prevalence of fenbendazole resistance in ovine nematodes in North West India. Trop. Anim. Hlth. Prod. 26: 230-234.

Kwa, M. S., Kooyman, F. N. J., Boersema, J. H., and Roos, M. H. 1993a. Effect of selection for benzimidazole resistance in Haemonchus contortus in $\beta$-tubulin isotype- 1 and isotype- 2 genes. Biochem. Biophys. Res. Commun. 191: 413-419.

Kwa, M. S., Veenstra, J. G. and Roos, M.H. 1994. Benzimidazole resistance in Haemonchus contortus is correlated with a conserved mutation at amino acid 200 in $\beta$-tubulin isotype-1. Mol. Biochem. Parasitol. 63: 299303.

Kwa, M. S., Veenstra, J. G., and Roos, M. H. 1993b. Molecular characterization of $\beta$ tubulin genes present in benzimidazole resistant populations of Haemonchus contortus. Mol. Biochem. Parasitol. 60: 133144.

Kwa, M. S., Veenstra, J. G., Dijk, M. D. and 
Roos, M. H. 1995. $\beta$-tubulin genes from the parasite nematode Haemonchus contortus modulate drug resistance in Caenorhabditis elegans. J. Mol. Biol. 246: 500-510.

Lacey, E. 1988. The role of the cytoskeletal protein, tubulin, in the mode of action and mechanism of drug resistance to benzimidazoles. Int. J. Parasitol. 18: 885-936.

Le Jambre, L. F. (1976). Egg hatch as an in vitro assay of thiabendazole resistance in nematodes. Veterinary Parasitology, 2(4), 385-391.

Le Jambre, L.F. 1978. Anthelmintic resistance in gastrointestinal nematodes of sheep. In "the Epidemiology and control of Gastrointestinal parasites of sheep in Australia. (A.D Donald, W.H Southcott and J.K Dineen, eds.). CSIRO, Melbourne: pp109-120.

Lind, E.O., Uggla, A., Waller, P. and Hoglund, J. 2005. Larval development assay for detection of anthelmintic resistance in Cyathostomins of Swedish horses. Vet. Parasitol. 128(3): 261-269.

Love, S. C. J., John, W. H and Coverdale, O. R. 1992. Anthelmintic resistance in sheep nematodes in New Zealand region of New South Wales. Aus. Vet. J. 69: 196-197.

Maharshi, A.K., Swarnkar, C.P., Singh, D., Manohar, G.S. and Ayub, M. 2011. Status of anthelmintic resistance in gastrointestinal nematodes of sheep in Rajasthan. Indian J. Anim. Sci. 81: 105-109.

Makvana, V.N. and Singh, V. 2009. Emergence of anthelmintic resistance in nematode parasites of sheep at an organized farm in Gujarat. J. Vet. Parasitol. 23(2):171-173.

Martin, P. J., Anderson N. and Jarrett, R. G. 1985. Resistant to benzimidazole anthelmintics in field strains of Ostertagia and Nematodirus in sheep. Aus. Vet. J. 62: 38-43.

Martin, P. J., Anderson, N., Jarrett, R. G., Brown, T. H. and Ford, G. E. 1982. Effects of a preventive and suppressive control scheme on the development of thiabendazole-resistance in Ostertagia spp. Aus. Vet. J. 58: 185-190.

Martin, P. J., Anderson, N., Lwin, T., Nelson, G. and Morgan, T. E. 1984. The association between frequency of thiabendazole treatment and the development of resistance in field isolates of Ostertagia spp. of sheep. Int. J. Parasitol. 14: 177-181.
McKenna, P. B. 1989. Multigeneric resistance to benzimidazole anthelmintics in sheep. New Zealand Vet. J. 37: 62-64.

McKenna, P. B., Badger, S. B., McKinley, R. L and Taylor, D. E. 1990. Simultaneous resistance to two or more broad spectrum anthelimintics by gastrointestinal nematode parasites of sheep and goats. New Zealand Vet. J. 38: 114-117.

Morales, G and Pino, L.A. 2001. Drogas antihelmínticas sobre estrongilos digestivos em ovinos estabulados. Rev. Cient. Vet. Trop. 26: 147-158.

O'Brien, T.F. 1997. The global epidemic nature of antimicrobial resistance and the need to monitor and manage it locally. Clin. Infect. Dis. 24 (S1): S2-S8.

Pape M, Von Samson-Himmelstjerna G and Schnieder T. 1999. Characterisation of the beta-tubulin gene of Cylicocyclus nassatus. Int. J. Parasitol. 29(12): 1941-1947.

Praslicka, J., Pilko, P., Varady, M. and Corba, J. 1995. Levamisole-and tetramisole-resistant gastrointestinal nematodes in sheep. Vet. Medicine, 40(2): 45-48.

Prichard, R. K. 1980. The problem of anthelmintic resistance in nematode. Aus. Vet. J. 56: 239250.

Prichard, R. K. 1990. Anthelminthic resistance in nematode extent, recent understanding and future direction for control and research. Int. J. Parasitol 20: 515-523.

Prichard, R. K. 2001. Genetic variability following selection of Haemonchus contortus with anthelmintics. Trends in Parasitol. 17: 445-453

Rajagopal, A., Radhika, R., Shameem, H. and Devada, K. 2013. Detection of anthelmintic resistance in small scale goat rearing units in Thrissur. J. Vet. Anim. Sci. 44: 51-53.

Ram, H., Rasool, T.J., Sharma, A.K., Meena, H.R. and Singh, S.K. 2007. Comparative efficacy of different anthelmintics against fenbendazole-resistant nematodes of Pashmina goats. Vet. Res. Com. 31(6): 719723.

Ramünke, S., Melville, L., Rinaldi, L., Hertzberg, H., de Waal, T., Von Samson-Himmelstjerna, G., Cringoli, G., Mavrot, F., Skuce, P., Krücken, J. and Demeler, J. 2016. Benzimidazole resistance survey for 
Haemonchus, Teladorsagia and Trichostrongylus in three European countries using pyrosequencing including the development of new assays for Trichostrongylus. Int. J. Parasitol. Drugs and Drug Resist. 6(3): 230-240.

Raymond, M., Callaghan, A., Fort, P. and Pasteur, N. 1991. Worldwide migration of amplified insecticide resistance genes in mosquitoes. Nature, 350: 151-153.

Rialch, A., Vatsya, S. and Kumar, R.R. 2013. Detection of benzimidazole resistance in gastrointestinal nematodes of sheep and goats of sub-Himalyan region of northern India using different tests. Vet. Parasitol. 198(3): 312-318.

Rolfe, P. F., Boray, J. C., Fitzgibbon, C., Parsons, G., Kensley, P. and Sangster, N. 1990. Closantel resistance in Haemonchus contortus from sheep. Aus. Vet. J. 67: 29-31.

Roos, M. H., Kwa, M. S. G. and Grant, W. N. 1995. New genetic and practical implications of selection for anthelmintic resistance in parasitic nematodes. Parasitol Today. 11: 148-150.

Round, M. C., Simpson, D. J., Haselden, C. S., Glendining, E. S. A and Baskerville, R. E. 1974. Horse strongyles tolerance to anthelmintics. Vet. Rec. 95: 517-518.

Roush, R.T. and McKenzie, J.A., 1987. Ecological genetics of insecticide and acaricide resistance. Ann. Rev. Entomol. 32(1): 361-380.

Rufener L., Kaminsky R. and Mäser P. 2009. In vitro selection of Haemonchus contortus for benzimidazole resistance reveals a mutation at amino acid 198 of beta-tubulin. Mol. Biochem. Parasitol. 168(1): 120-122.

Sangstar, N. C. 1990. Biochemical diagnosis of anthelmintic resistance. In: Boray, J.C., Martin, P. J., Roush, R. T. (Eds).Resistance of parasites to antiparasitic drugs, I COPA VII. MSD, Agvt. New Jersey, pp. 171-176.

Sangster, N. C. 1996. Pharmacology of anthelmintic resistance. Parasitol. 113: 201216.

Sangster, N. C., Prichard, R. K., and Lacey, E. 1985. Tubulin and benzimidazole resistance in Trichostrongylus colubriformis (nematoda). J. parasitol. 7: 645-651.

Sangster, N. C., Rickard, J., Hennessy, D. R., and
Steel, J. W. 1991. Disposition of oxfendazole in goats and efficacy compared with sheep. Res. Vet. Sci. 51: 258-263.

Sangster, N. C., Whitlock, H. V., Russ, I. G., Gunawan, M., Griffin, D. L. and Kelly, J. D. 1979. Trichostrongylus colubriformis and Ostertagia circumcinta resistant to levamisole, morantel tartrate and thiabendazole; occurrence of field strains. Res. Vet. Sci. 27: 106-110.

Sankar, M. 2003. Studies on benzimidazole resistance in $H$. contortus in sheep. Thesis, M.V.Sc. Deemed University, Indian Veterinary Research Institute, Izatnagar, India.

Sankar, M. 2007. Molecular characterization of $\beta$ tubulin gene in benzimidazole resistant and susceptible populations of common gastrointestinal nematodes in small ruminants. Thesis, Ph.D. Deemed University, Indian Veterinary Research Institute, Izatnagar, India.

Sanyal P.K. 1993. Plasma level of fenbendazole metabolities in buffalo and cattle after long term intraruminal administration. The Vet. Quart. 15: 157-159.

Sanyal P.K. 1994. The pharmacokinetic behaviour of fenbendazole in buffalo and cattle. J. Vet. Pharmaco. Therap. 17: 1-4.

Sanyal, P. K. and Godke, Y. 1996. The influence of species and sub clinical parasitism on the kinetic disposition of fenbendazole in domestic small ruminants. Indian. Vet. J. 73: 392-395.

Sarangi, D., Mohanty, B.N., Panda, M.R., Karna, D.K. and Dehuri, M. 2014. Comparative evaluation of anthelmintic efficacy of chemotherapeutics against natural infestation of gastro-intestinal nematodes in caprines. Intas Polivet, 15(1): 115-117.

Silvestre, A. and Humbert, J.F. 2000. A molecular tool for species identification and benzimidazole resistance diagnosis in larval communities of small ruminant parasites. Exp. Parasitol. 95: 271-276.

Silvestre, A., Cabaret, J., and Humbert, J. F. 2001. Effect of benzimidazole underdosing on the resistant allele frequency in Teladorsagia circumcincta (nematoda). Parasitol. 123: 103111.

Silvestre, A., Chartier, C., Saure, C., and Cabaret, 
J. 2000. Relationship between helminth species diversity, intensity of infection and breeding management in dairy goats. Vet. Parasitol. 94: 91-105.

Singh, D., Gulyani, R. and Bhasin, V. 1992. Occurrence of thiabendazole resistant strains of Haemonchus contortus in sheep. Indian Vet. Med. J. 16: 139-141.

Singh, D., Swarnkar, C.P. and Khan, F.A. 2002. Anthelmintic resistance in gastrointestinal nematodes of livestock in India. J. Vet. Parasitol. 16: 115-130.

Singh, D., Swarnkar, C.P., Khan, F.A., Srivastava, C.P. and Bhagwan, P.S.K. 1995. Resistance to albendazole in gastrointestinal nematodes of sheep. J. Vet. Parasitol. 9(2): 95.

Singh, D., Swarnkar, C.P., Srivastava, C.P., Bhagwan, P.S.K. and Dimri, U. 1996. Haemonchus contortus resistance to rafoxanide in sheep. J. Vet. Parasitol. 10(1): 53.

Singh, S., Yadav, C.L., and Banerjee, D.P. 1997. Comparison of the post parturient rise in faecal egg counts of indigenous and crossbred ewes. J. Helminthol. 71(3): 249-252.

Smith, G. 1990. A mathematical model for the evolution of anthelmintic resistance in a direct life cycle nematode parasite. Int. J. Parasitol. 20: 913-921.

Soulsby, E. J. L. 1982. Helminths, Arthropods and Protozoa of domesticated animals. $7^{\text {th }}$ edn. Billiere Tindell, London

Srivastava, V. K., Kumar, P.N., Khanna, P.N. and Singh, M. 1995. Gastrointestinal nematodiasis and drug resistance in sheep. Ind. Vet. J. 72: 14-16.

Sundaram, A.M., John, L. and Sundar, N. 2005. Detection of levamisole resistance in sheep in Tamil Nadu using in vitro egg hatch assay. Indian J. Small Rum. 11(2):214-215.

Swarnkar, C. P., Sanyal, P. A., Singh, D., Khan, F. A. and Bhagawan, P. S. K. 2001. Anthelmintic resistance on organized sheep farm in India. Trop. Health. Anim. Prod. 33: 305-312.

Swarnkar, C. P., Singh, D., Khan, F. A. and Bhagawan, P. S. K. 1999b. Multiple anthelmintic resistance in $H$. contortus of sheep. Ind. J. Anim. Sci. 69: 547-549.

Swarnkar, C.P., Khan, F.A., Singh D. and Bhagwan, P.S.K. 1999a. Further studies on anthelmintic resistance in sheep at an organized farm in arid region of rajasthan. Vet. Parasitol. 82: 83-84.

Sykes, A.R., McFralane, R.G. and Familton, A.S. 1992. Parasites immunity and anthelmintic resitance. In progress in sheep and goat research (A.W. speedy ed): CAB international Wallingford. pp 179-191.

Tandon, R. and Kaplan, R.M. 2004. Evaluation of a larval development assay (DrenchRite) for the detection of antihelmintic resistance in cyathostomin nematodes of horses. Vet. Parasitol. 121(1): 125-142.

Taylor, M.A. 1990. A larval development test for the detection of an anthelmintic resistance in nematode of sheep. Res. Vet sci. 49: 198-202.

Taylor, M.A. and Hunt, K.R. 1989. Anthelmintic drug resistance in the UK. Ve. Rec. 125: 143147.

Tiwari, J., Kolte, A.P., Kumar, S., Swarnkar, C.P., Singh, D. and Pathak, K.M.L. 2007. Diagnosis of benzimidazole resistance in Haemonchus contortus of sheep by allele specific PCR. Asian

Tiwari, J., Kumar, S., Kolte, A.P., Swarnkar, C.P., Singh, D. and Pathak, K.M.L. 2006. Detection of benzimidazole resistance in Haemonchus contortus using RFLP-PCR technique. Vet. Parasitol. 138(3): 301-307.

Uppal, R.P., Yadav, C.L., Godara, P., and Rana, J.S. 1992. Multiple anthelmintic resistance in a field strain of Haemonchus contortus in goats. Vet. Res. Com. 16: 195-198.

Van Wyk, J.A., Malan, F.S., Gerber, H.M and Alves, R.M.R. 1987. Two field strains of Haemonchus contortus resistant to rafoxanide. Onderstepoort J. Vet. Res. 54: 143-146.

Van Wyk, J.A., Malan, F.S., Gerber, H.M and Alves, R.M.R. 1989. The problem of escalating resistance of Haemonchus contortus to the modern anthelmintics in South Africa. Onderstepoort J. Vet. Res. 56: 41-49.

Van Wyk., J.A., and VanSchalKwyk, P.C. 1990. A novel approach to the control of anthelmintic resistant Haemonchous contortus in sheep. Vet. Parasitol. 35: 61-69.

Varady, M. and Corba, J. 1999. Comparison of six in vitro test in determining benzimidazole and levamisole resistance in Haemonchus 
contortus and Ostertagia circumcincta of sheep. Vet Parasitol. 80(3): 239-249.

Varshney, T.R and Singh and Y.P. 1976. A note on development of resistance of Haemonchus contortus worm against phenothiazine and thiabendazole in sheep. Indian. J. Anim. Sci. 46: 666-668.

Veneziano, V., Rubino, R., Fedele, V., Rinaldi, L., Santaniello, M., Schioppi, M., Cascone, C., Pizzillo, M. and Cringoli, G. 2004. The effects of five anthelmintic treatment regimes on milk production in goats naturally infected by gastrointestinal nematodes. South Afr. J. Anim. Sci. 34: 238-240.

Von Samson-Himmelstjerna G., Harder A., Pape M. and Schnieder T. 2001. Novel small strongyle (Cyathostominae) beta-tubulin sequences. Parasitol. Res. 87(2): 122-25.

Von Samson-Himmelstjerna, G., Pape, M. and Witzendorff, C.von, Schnieder, T. 2002a. Allele-specific PCR for the beta-tubulin codon 200 TTC/TAC polymorphism using single adult and larval small strongyle (cyathostominae) stages. J. Parasitol. 88(2): 254-257.

Von Samson-Himmelstjerna, G., Witzendorff, C.von, Sievers, G. and Schnieder, T. 2002b. Comparative use of faecal egg count reduction test, egg hatch assay and betatubulin codon 200 genotyping in small strongyles (cyathostominae) before and after benzimidazole treatment. Vet. Parasitol. 108(3): 227-235.

Waller P.J. Echevarria F., Eddi, C., Macial, S., Nari, A. and Hensen, J.W. 1996. The prevalence of anthelmintic resistance in nematode parasites of sheep in southern Latin America: general overview. Vet. Parasitol.
62: 181.

Waller, P.J. 1997. Anthelmintic resistance. Vet Parasitol. 72(3): 391-405.

Waller, P.J. 1999. International approaches to the concept of integrated control of nematode parasites of livestock. Int. J. Parasitol. 29(1): 155-164.

Watson, T.G and Hosking, B.C. 1990. Evidence for multiple anthelmintic resistance in two nematode parasite genera on a Saanen goat diary. New Zealand Vet. J. 38: 50-53.

Wood, R.J. and Mani, G.S. 1981. The effective dominance of resistance genes in relation to the evolution of resistance. Pesticide sci. 12(5): 573-581.

Yadav C.L.1990. Fenbendazole resistance in Haemonchus contortus of sheep. Vet. Rec. 126: 586.

Yadav C.L., Uppal, R.P., and kalra, S. 1993. An outbreak of haemonchosis associated with anthelmintic resistance in sheep. Int. J. Parasitol. 23(3): 411-413.

Yadav C.L., Uppal, R.P., and Prerna. 1992. Clinical trail with closantel against Haemonchus contortus in kids. Ind. Vet. J. 69: 742-745.

Yadav, C.L. and Verma, S.P. 1997. Morantel resistance by Haemonchus placei in cattle. Vet. Rec. 141(19): 499-500.

Yadav, C.L., Ghorui, S.K., Singh, B.P. and Sharma, M.C. 1996. Benzimidazole resistance in Haemonchus contortus of sheep and goats in Uttar Pradesh. J. Vet. Parasitol. 10(1): 47-51.

Yadav, R. Kumar, R. P. Uppal and Verma.1995. Multiple anthelmintic resistance in Haemonchus contortus on a sheep form in India. Vet. Parasitol. 60: 355-360.

\section{How to cite this article:}

Bhinsara, D.B., M. Sankar, D.N. Desai, J.J. Hasnani, P.V. Patel, N.D. Hirani and Chauhan, V.D. 2018. Benzimidazole Resistance: An Overview. Int.J.Curr.Microbiol.App.Sci. 7(02): 3091-3104. doi: https://doi.org/10.20546/ijcmas.2018.702.372 